ISSN 2236-0859

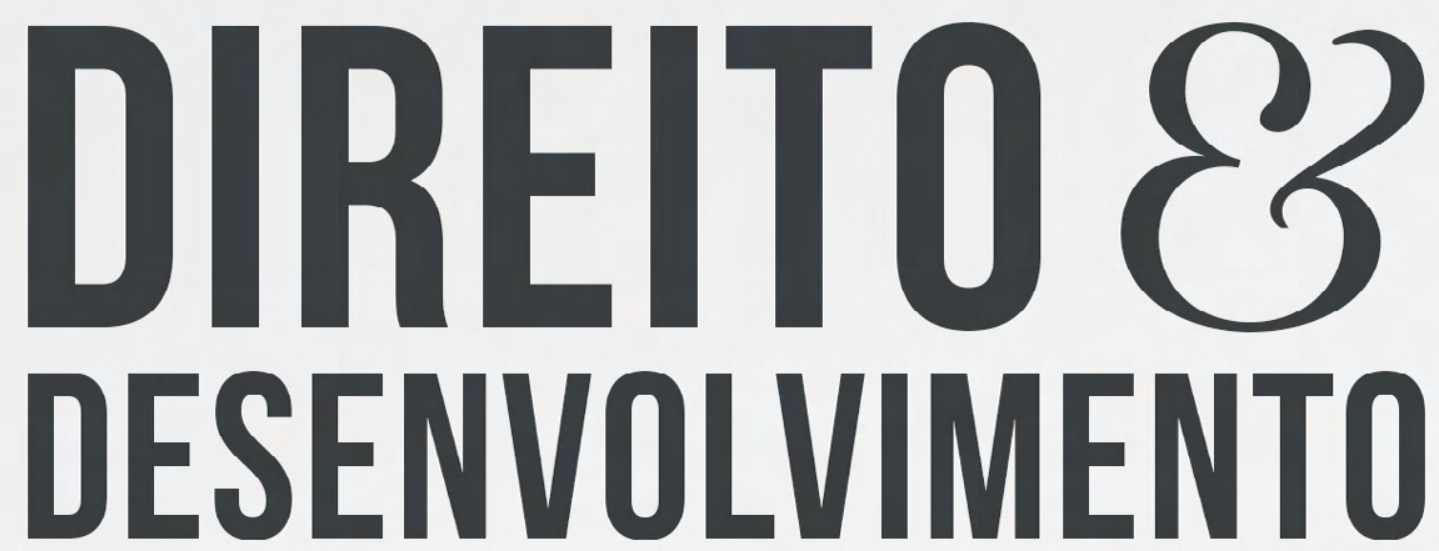

REVISTA DO PROGRAMA DE PÓS-GRADUAÇÃO EM DIREITO MESTRADO EM DIREITO E DESENVOLVIMENTO SUSTENTÁVEL

ASPECTOS MATERIAIS E PROCESSUAIS DA APLICAÇÃO DA TEORIA DA DESCONSIDERAÇÃO DA PERSONALIDADE JURÍDICA NA SOLUÇÃODE LITÍGIOS RELACIONADOS A RELAÇÕES DE CONSUMO

JOSÉ TADEU NEVES XAVIER 


\title{
ASPECTOS MATERIAIS E PROCESSUAIS DA APLICAÇÃO DA TEORIA DA DESCONSIDERAÇÃO DA PERSONALIDADE JURÍDICA NA SOLUÇÃO DE LITÍGIOS RELACIONADOS A RELAÇÕES DE CONSUMO
}

\section{MATERIAL AND PROCEDURAL ASPECTS OF THE APPLICATION OF THE DISREGARD OF LEGAL ENTITY IN THE SOLUTION OF LITIGATIONS RELATED TO CONSUMER LAW}

Recebido: 31/07/2018

Aprovado: 10/11/2018

José Tadeu Neves Xavier*

RESUMO: A teoria da desconsideração da personalidade jurídica é um importante instrumento de controle de condutas que representem a utilização abusiva das prerrogativas inerentes aos entes personificados, em especial nos casos em que este usufrui de limitação de responsabilidade. O Código de Defesa do Consumidor foi a primeira espécie normativa a tipificar esta figura jurídica, atribuindo-lhe caracteres especiais afinados com o seu escopo maior que é a efetiva tutela dos consumidores. O advento do Código de Processo Civil de 2015 trouxe a regulamentação procedimental da aplicação da teoria da desconsideração, acentuando o debate sobre a sua adequação aos litígios envolvendo direitos de consumidores.

Palavras-chave: Direito do consumidor. Teoria da desconsideração da personalidade jurídica. Tutela dos consumidores

\begin{abstract}
Piercing the corporate veil is an important instrument for controlling abusive conduct of the prerogatives inherent to the legal entities, especially in cases in which those corporations hold limitation of liability. The Consumer Code has been the first normative species to typify this legal figure, attributing it special characters in tune with its greater scope that is the effective guardianship of the consumer rights. The Code of Civil Procedure of 2015 issue brought the procedural regulation of the application of the theory of disregard, accentuating the debate on its adequacy to the litigations involving consumer rights.
\end{abstract}

Keywords: Consumer law. Theory of disregard of legal entity. Consumer protection.

\section{INTRODUÇÃO}

A teoria da desconsideração da personalidade jurídica foi inserida no cenário nacional por influência da doutrina. O pioneirismo é atribuído ao jurista Rubens Requião, que em 1969, que proferiu conferência sobre o tema na Faculdade de Direito da Universidade Federal do Paraná, a qual teve versão escrita publicada sob o título Abuso e fraude através da personalidade jurídica (disregard doctrine) ${ }^{2}$. A esse trabalho se sucederam dois estudos considerados clássicos

\footnotetext{
* Pós- Doutor em Direito pela Universidade de Santiago de Compostela (Espanha). Doutor e Mestre em Direito pela Universidade Federal do Rio Grande do Sul (UFRGS), professor na Faculdade de Direito da Fundação Escola Superior do Ministério Público FMP (Graduação e Mestrado em Direito), na Escola da Magistratura do Trabalho do Rio Grande do Sul (FEMARGS), e na Faculdade Meridional - IMED. Advogado da União. E-mail: jtadeunx@terra.com.br 2 REQUIÃO, Rubens. Abuso e fraude através da personalidade jurídica (disregard doctrine). Revista dos Tribunais, vol. 410, dez. de 1969, p. 12-24.
} 
na abordagem do assunto: em 1976 Fábio Konder Comparato publicou a obra Poder de controle na sociedade anônima ${ }^{3}$ e, em 1979, José Lamartine Corrêa de Oliveira editou ensaio intitulado A dupla crise da pessoa jurídica ${ }^{4}$.

Na seara normativa a primeira legislação a positivar a disregard doctrine foi o Código de Defesa do Consumidor ${ }^{5}$, sendo seguido, em 1994, pela Lei Antitruste - Lei ${ }^{0}$ 8.884/946 (atualmente substituída pela Lei $\mathrm{n}^{0} 12.259 / 2011^{7}$ ). Após veio a Lei $\mathrm{n}^{\circ}$ 9.605/95, sobre a responsabilidade ambiental ${ }^{8}$. Finalmente, a Codificação Civil de 2002 trouxe a cláusula geral da teoria da desconsideração para o direito privado nacional, em seu artigo 50, nos seguintes termos: "Em caso de abuso da personalidade jurídica, caracterizado pelo desvio de finalidade, ou pela confusão patrimonial, pode o juiz decidir, a requerimento da parte, ou do Ministério Público quando lhe couber intervir no processo, que os efeitos de certas e determinadas relações de obrigações sejam estendidos aos bens particulares dos administradores ou sócios da pessoa jurídica"9. Mais recentemente a legislação anticorrupção (Lei $n^{0}$ 12.846/2013) normatizou a desconsideração na seara administrativa ${ }^{10}$.

O mosaico referente à normatização da doutrina da desconsideração da personalidade jurídica propiciou a consolidação de duas teorias, elaboradas por Fábio Ulhoa Coelho, para organização e sistematização da matéria, chamadas de teoria maior e menor ${ }^{11}$. A primeira não se contenta com a mera insolvência patrimonial da pessoa jurídica para que se busque a responsabilidade pessoal dos seus membros ou administradores, impondo também a necessidade de existência de abuso na utilização da entidade personificada. A sua incidência é verificada na aplicação das disposições constantes do art. 50 do CC, 28, caput, do CDC, e na legislação antitruste. A teoria menor, por sua vez, autoriza o levantamento do véu que encobre a entidade pela mera verificação de insolvência da pessoa jurídica que vier a ocasionar prejuízos à realização dos direitos dos credores. Nesta modalidade a análise da ocorrência de conduta abusiva na utilização do entre personificado é despicienda. Esta versão é efetivada na aplicação da previsão constante do $\S 5^{\circ}$ do art. 28 do CDC e no regramento sobre de responsabilidade ambiental.

3 COMPARATO, Fábio Konder. Poder de controle na sociedade anônima, São Paulo: Revista dos Tribunais, 1976. Esta obra conta com edição atualizada por Calixto Salomão Filho (O poder de controle na sociedade anônima 6aㅡ ed., São Paulo: Revista dos Tribunais, 2014).

4 OLIVEIRA, José Lamartine Corrêa de. A dupla crise da pessoa jurídica, São Paulo: Saraiva, 1979.

5 Código de Defesa do Consumidor, art. 28, caput e $§ 5^{\mathbf{0}}$, respectivamente: "O juiz poderá desconsiderar a personalidade jurídica da sociedade quando, em detrimento do consumidor, houver abuso de direito, excesso de poder, infração da lei, fato ou ato ilícito ou violação dos estatutos ou contrato social. A desconsideração também será efetivada quando houver falência, estado de insolvência, encerramento ou inatividade da pessoa jurídica provocados por má administração"; "Também poderá ser desconsiderada a pessoa jurídica sempre que a sua personalidade for, de alguma forma, obstáculo ao ressarcimento de prejuízos causados aos consumidores 6 Lei no 8.884/94, art. 18: “A personalidade jurídica do responsável por infração da ordem econômica poderá ser desconsiderada quando houver da parte deste abuso de direito, excesso de poder, infração da lei, fato ou ato ilícito ou violação dos estatutos ou contrato social. A desconsideração também será efetivada quando houver falência, estado de insolvência, encerramento ou inatividade da pessoa jurídica provocados por má administração”.

7 Lei no 12.259/2011, art. 34: “A personalidade jurídica do responsável por infração da ordem econômica poderá ser desconsiderada quando houver da parte deste abuso de direito, excesso de poder, infração da lei, fato ou ato ilícito ou violação dos estatutos ou contrato social. Parágrafo único. A desconsideração também será efetivada quando houver falência, estado de insolvência, encerramento ou inatividade da pessoa jurídica provocados por má administração”.

8 Lei n⿳0 9.605/95, art. 4: "Poderá ser desconsiderada a pessoa jurídica sempre que sua personalidade for obstáculo ao ressarcimento de prejuízos causados à qualidade do meio ambiente

9 Em relação à análise do art. 50 do Código Civil remetemos o leitor a: XAVIER, José Tadeu Neves. A teoria da desconsideração da personalidade jurídica no novo Código Civil, Revista de Direito Privado, $n^{\circ} 10,2002$, p. $69-85$.

10 Lei no 12.846/2013, art. 14: "A personalidade jurídica poderá ser desconsiderada sempre que utilizada com abuso do direito para facilitar, encobrir ou dissimular a prática de atos ilícitos previstos nesta Lei ou para provocar confusão patrimonial, sendo estendidos todos os efeitos das sanções aplicadas à pessoa jurídica aos seus administradores e sócios com poderes de administração, observados o contraditório e a ampla defesa".

11 COELHO, Fábio Ulhoa. Desconsideração da personalidade jurídica, São Paulo: Revista dos Tribunais, 1989. A referência à teoria maior e menor da desconsideração da personalidade jurídica foi, posteriormente, abandonada por Fábio Ulhoa Coelho, chegando a consignar: "em 1999, quando era significativa a quantidade de decisões judiciais desvirtuando a teoria de desconsideração, cheguei a chamar sua aplicação incorreta de 'teoria menor', reservando à correta a expressão 'teoria maior'. Mas a evolução do tema na jurisprudência brasileira não permite mais falar-se em teorias distintas, razão pela qual esses conceitos de 'maior' e 'menor' mostram-se, agora, felizmente, ultrapassados” - COELHO, Fábio Ulhoa. Curso de Direito Comercial: v. 2, Direito de Empresa, 20a ed., São Paulo: Revista dos Tribunais, 2016, p. 7o. Porém, tal formulação parece ter alçado vida própria, e continua sendo corrente tanto em nível doutrinário como pretoriano. 
A autonomia e, por conseguinte, o convívio dessas teorias sobre a aplicação da disregard doctrine em nosso sistema jurídico, foi ratificada nas Jornadas de Direito Civil ${ }^{12}$, com a criação do enunciado $n^{-}$51, concluindo que: "A teoria da desconsideração da personalidade jurídica disregard doctrine - fica positivada no novo Código Civil, mantidos os parâmetros existentes nos microssistemas legais e na construção jurídica sobre o tema”’3.

O presente ensaio se dedica, especificamente, à concepção e aplicação da teoria da desconsideração nas questões pertinentes às relações de consumo.

\section{A DESCONSIDERAÇÃO DA PERSONALIDADE JURÍDICA NAS RELAÇÕES DE CONSUMO}

Visando à harmonia nas relações de consumo, consubstanciada no equilíbrio entre consumidor e fornecedor, com a proteção da parte mais fraca e mais vulnerável, e que sempre esteve subjugada pelos controladores do mercado de consumo, o Código Consumerista trouxe a possibilidade expressa de superação da personalidade jurídica do fornecedor para proporcionar ao consumidor a satisfação de seu direito de crédito perante os sócios da empresa ${ }^{14}$.

Porém, no âmbito do Direito Consumerista, a teoria da desconsideração da personalidade jurídica ganhou contornos próprios, aptos a corresponder à forma diferenciada de tutela do consumidor nas relações de consumo. Nas palavras de Cláudia Lima Marques "no CDC, o método é mais uma vez tópico e funcional, bem ao gosto do CDC, no sentido de resolver o problema concreto do conflito de valores entre a manutenção do dogma da separação patrimonial e os interesses da outra parte contratante com a pessoa jurídica insolvente" ${ }^{\prime \prime}$.

A previsão normativa da teoria da desconsideração na Legislação Consumerista apresenta-se como um retoque final dado pelo legislador ao sistema de responsabilidades na relação de consumo, pois está prevista no final do Capítulo que cuida da qualidade dos produtos e serviços e da prevenção e da reparação dos danos causados ao consumidor. Este viés deve estar presente pelo intérprete e aplicador na atividade de subsunção de cada uma das normas e princípios do Direito do Consumidor. Trata-se de regra matriz da interpretação das normas consumeristas.

Assim, de início, devemos buscar uma exata delimitação da teoria da desconsideração da personalidade jurídica neste Código Protetivo, pois em dois momentos o legislador consumerista referiu sob a rubrica da desconsideração da personalidade jurídica matérias de responsabilidade subsidiária e solidária, ou seja, nos casos de grupos e consórcio de empresas. Os $\S \S 2^{\circ}, 3^{\circ}$ e $4^{\underline{o}}$ do art. 28, do Código Consumerista, contemplam hipóteses que

\footnotetext{
12 Há uma série de outros enunciados nas Jornadas de Direito Civil destinados ao tema da teoria da desconsideração da personalidade jurídica. Vejamos: enunciado no 7 - art. 50: Só se aplica a desconsideração da personalidade jurídica quando houver a prática de ato irregular e, limitadamente, aos administradores ou sócios que nela hajam incorrido; enunciado no 146 - art. 50 : Nas relações civis, interpretam-se restritivamente os parâmetros de desconsideração da personalidade jurídica previstos no art. 50 (desvio de finalidade social ou confusão patrimonial; enunciado no 281 - art. 50: A aplicação da teoria da desconsideração, descrita no art. 50 do Código Civil, prescinde da demonstração de insolvência da pessoa jurídica; enunciado no 282 - art. 50: $O$ encerramento irregular das atividades da pessoa jurídica, por si só, não basta para caracterizar abuso da personalidade jurídica; enunciado no 283 - art. 50 : $E^{2}$ cabível a desconsideração da personalidade jurídica denominada "inversa" para alcançar bens de sócio que se valeu da pessoa jurídica para ocultar ou desviar bens pessoais, com prejuízo a terceiros; enunciado no 284 - art. 50: As pessoas jurídicas de direito privado sem fins lucrativos ou de fins não econômicos estão abrangidas no conceito de abuso da personalidade jurídica; enunciado n-285 - art. 50: A teoria da desconsideração, prevista no art. 50 do Código Civil, pode ser invocada pela pessoa jurídica, em seu favor.

$13 \mathrm{Na}$ Jornada da disciplina mercantil foi publicado o enunciado $\mathrm{n}^{\circ}$ 9, dispondo: Quando aplicado às relações jurídicas empresariais, o art. 50 do Código Civil não pode ser interpretado analogamente ao art. $28, \$ 5^{\circ}$, do CDC ou ao art. $2^{\circ}$, $\$ 2^{\circ}$, da CLT.

14 O jurista Caio Mário da Silva Pereira refere expressamente: "a maior inovação trazida pelo Código do Consumidor foi a doutrina da desconsideração da pessoa jurídica” (PEREIRA, Caio Mário da Silva. Responsabilidade civil, (aspectos) no código de proteção e defesa do consumidor, desconsideração da personalidade jurídica. Revista da Academia Brasileira de Letras Jurídicas, v. 9, no 7, p. 13o). 15 MARQUES, Claudia Lima. Contratos no Código de Defesa do Consumidor: o novo regime das relações contratuais, 8ª ed., São Paulo: RT, 2016, p. 1.410.
} 
não correspondem à aplicação da disregard doctrine e, sim de responsabilidade solidária e subsidiária, motivo pelo qual não serão analisados no presente ensaio.

Devidamente afastadas as hipóteses previstas no artigo 28 do Código de Defesa do Consumidor em que não se verifica verdadeiramente a previsão normativa da teoria da desconsideração da personalidade jurídica, restam três situações estabelecidas pelo legislador consumerista: (a) quando, em detrimento do consumidor, houver abuso de direito, excesso de poder, infração da lei, fato ou ato ilícito ou violação dos estatutos e contrato social; (b) nos casos de falência, estado de insolvência, encerramento ou inatividade da pessoa jurídica provocados por má-administração; (c) Sempre que a personalidade societária for, de alguma forma, obstáculo ao ressarcimento de prejuízos causados ao consumidor.

No primeiro caso temos o condicionante legal que é a lesão dos interesses do consumidor, ou seja, somente será possível o uso da desconsideração se restar evidenciado que a prática abusiva ou ilícita foi praticada em detrimento do consumidor. $\mathrm{O}$ abuso de direito coloca-se como o exercício não regular de um direito reconhecido, autorizando o levantamento do véu societário, pois, nas palavras de Marlon Tomazette "a personalidade jurídica é atribuída visando determinada finalidade social: se qualquer ato é praticado em desacordo com tal finalidade, causando prejuízos a outrem, tal ato é abusivo e, por conseguinte, atentatório ao direito, sendo a desconsideração um meio efetivo de repressão a tais práticas" ${ }^{{ }_{1} 6}$. Luciano Amaro, ao analisar esta hipótese legal, lembra que somente será aplicada a teoria da desconsideração do ente societário, nesta hipótese, quando estiver presente a incapacidade financeira da pessoa jurídica para ressarcir o dano causado ao consumidor ${ }^{17}$, pois o caráter excepcional da efetivação da disregard doctrine é e deve ser preservado, mesmo frente à capitulação legal de conduta específica autorizada da sua aplicação. Também está autorizada a superação da personalidade jurídica da sociedade fornecedora quando verificada conduta representativa de excesso de poder, ou seja, se os administradores entidade societária assumirem conduta que vai além dos limites fixados em lei, no contrato social ou no estatuto.

A doutrina, de um modo geral, não demonstra simpatia à dicção legislativa que inclui excesso de poder, infração da lei, fato ou ato ilícito ou violação dos estatutos e contrato social como motivos ensejadores da efetivação da extensão da responsabilidade da pessoa jurídica aos seus membros ou administradores, enxergando aqui a presença de meras condutas justificadoras de responsabilidade pessoal dos autores da prática de tais atos.

Na segunda hipótese, a intenção de causar prejuízo ao consumidor é afastada e o elemento justificador da aplicação da superação da desconsideração jurídica é a verificação de má-administração societária, que ocasione desfalque patrimonial da empresa, atingindo indiretamente o crédito do consumidor ${ }^{18}$. Assim, ocorrendo falência, encerramento ou inatividade da empresa, somente será utilizada a técnica da desconsideração quando a causa destas puder ser atribuída à má-administração societária ${ }^{19}$.

16 TOMAZETTE, Marlon. Curso de Direito Empresarial: Teoria geral e direito societário, v. 1, 6ạ ed., São Paulo: Atlas, 2014 , p. 258. 17 AMARO, Luciano. Desconsideração da pessoa jurídica no Código de Defesa do Consumidor, Revista de Direito do Consumidor, v. 5, jan-mar de 1993, p. 168-182, RTonline.

18 A má-administração atinge primeiramente a própria empresa, causando seus efeitos danosos diretamente nesta, pelo que se pode dizer que neste caso o consumidor é atingido indiretamente.

19 O Tribunal de Alçada de Minas Gerais aplicou a teoria da desconsideração nesta hipótese em acórdão assim ementado: “ $A$ responsabilidade Civil do Administrador, para efeitos da desconsideração da personalidade jurídica (art. 28 da Lei $8078 / 90)$, se mantém, mesmo após a cessação de suas funções na sociedade. A administração da empresa é composta de atos contínuos, que se encadeiam e não se podem individualizar em curto lapso de tempo. O fato de o administrador ter se afastado do conselho de administração da sociedade, que se encontra em processo de liquidação extrajudicial, por si só, não significa que o mesmo esta desvinculado das ações que praticou no comando da organização, podendo vir a responder pelas consequências da má administração, se a deficiência de sua conduta restar configurada" (Ap. Civ. no $\mathbf{1 8 6 . 2 1 8 - 2 , ~ d a ~ C o m a r c a ~ d e ~ B e l o ~ H o r i z o n t e ) . ~ T a m b e ́ m ~ c a b e ~ c o n f e r i r ~}$ julgamento do recurso especial no Recurso especial 7370oo/MG, relatado pelo Min. Paulo de Tarso Sanseverino, j. pela $3^{\underline{a}}$ Turma do STJ, em 01/o9/2011: "Ação de resolução de contrato de promessa de compra e venda de imóvel proposta contra a construtora e seus sócios. Desconsideração da personalidade jurídica. Art. 28, caput e $\$ 5^{\circ}$, do CDC. Prejuízo a consumidores. Inatividade da empresa por má administração. 1. Ação de resolução de contrato de promessa de compra e venda de imóvel movida contra a construtora e seus sócios. 2. Reconhecimento pelas instâncias ordinárias de que, em detrimento das consumidoras demandantes, houve inatividade 
A terceira situação autorizadora da efetivação da disregard doctrine no âmbito consumerista será analisada no próximo tópico.

\subsection{A Desconsideração da personalidade jurídica em função do prejuízo}

A previsão expressa no parágrafo $5^{\circ}$, do artigo 28 , do Código Consumerista, inova na própria teoria da desconsideração da personalidade jurídica. Ela estabelece que esta doutrina deverá ser utilizada sempre que, de alguma forma, o reconhecimento irrestrito da personalidade jurídica da sociedade representar obstáculos ao ressarcimento de prejuízos causados a consumidores. Aqui, vigora o que ficou conhecido na doutrina como teoria menor da desconsideração, na qual são desprezados os questionamentos sobre aspectos subjetivos, como a má-fé, a fraude, bastando para tanto a insolvência do fornecedor ${ }^{20}$.

A amplitude estabelecida por este parágrafo, quanto à utilização da teoria da desconsideração, bem como o fato de possuir uma abrangência maior que o próprio caput do artigo, foi alvo de severas críticas entre os doutrinadores brasileiros. Alexandre Freitas de Assumpção Alves, nesta linha, sugere que a amplitude da norma e o âmbito de sua incidência devem ser estritamente interpretados, argumentando, ainda na vigência da Codificação Civil revogada, que: "qualquer prejuízo patrimonial sofrido pelo consumidor quando o agente é uma pessoa jurídica não pode levar ao afastamento de sua personalidade, pois, desta forma, estaria sendo eliminando o art. 20 do Código Civil e a aplicação da lei seria contrária aos fundamentos da República (art. 1º, IV) e da ordem econômica (art. 170, IV)", concluindo: "se o que se pretende é um aprimoramento do instituto da pessoa jurídica, não é possível sujeitar os sócios que ingressam na sociedade sob a garantia da limitação de sua responsabilidade e desvinculação de seus patrimônios à simples insatisfação de qualquer credor, ainda que seja um consumidor"21.

da pessoa jurídica, decorrente da má administração, circunstância apta, de per si, a ensejar a desconsideração, com fundamento no art. 28, caput, do CDC. 3. No contexto das relações de consumo, em atenção ao art. 28 , $\$ 5^{\circ}$, do CDC, os credores não negociais da pessoa jurídica podem ter acesso ao patrimônio dos sócios, mediante a aplicação da disregard doctrine, bastando a caracterização da dificuldade de reparação dos prejuízos sofridos em face da insolvência da sociedade empresária. 4. Precedente específico desta Corte acerca do tema (REsp. no 279.273/SP, Rel. Min. Ari Pargendler, Rel. p/ Acórdão Min. NANCY ANDRIGHI, Terceira Turma, DJ de 29.03.2004). 5. Recurso especial conhecido e provido".

20 A aplicação da teoria menor da desconsideração da personalidade jurídica em matéria consumerista foi contemplada em decisão do STJ proferida em demanda onde foi questionada a responsabilidade frente a danos causados em função de uma explosão em um shopping center na cidade de Osasco, fato este que ganhou repercussão nacional. O acordão recebeu a seguinte ementa: "Responsabilidade civil e Direito do Consumidor - Recurso especial - Shopping Osasco-SP - Explosão - Consumidores Danos materiais e morais - Ministério Público - Legitimidade ativa - Pessoa jurídica - Desconsideração - Teoria maior e teoria menor - Limite de responsabilização dos sócios - Código de Defesa do Consumidor - Requisitos - Obstáculo ao ressarcimento de prejuízos causados aos consumidores - art. $28, \$ 5^{\circ}$. (...) A teoria menor da desconsideração, acolhida em nosso ordenamento jurídico excepcionalmente no direito do consumidor e no direito ambiental, incide com a mera prova de insolvência da pessoa jurídica para o pagamento de suas obrigações, independentemente da existência de desvio de finalidade ou de confusão patrimonial. Para a teoria menor, o risco empresarial normal às atividades econômicas não pode ser suportado pelo terceiro que contratou com a pessoa jurídica, mas pelos sócios e/ou administradores desta, ainda que estes demonstrem conduta administrativa proba, isto é, mesmo que não exista qualquer prova capaz de identificar conduta culposa ou dolosa por parte dos sócios e/ou administradores da pessoa jurídica. A aplicação da teoria menor da desconsideração às relações de consumo está calcada na exegese autônoma do art. 5 o do art. 28 do CDC, porquanto a incidência desse dispositivo não se subordina à demonstração dos requisitos previstos no caput do artigo indicado, mas apenas á prova de causar, a mera existência da pessoa jurídica, obstáculo ao ressarcimento de prejuízos causados aos consumidores. Recursos especiais não conhecidos”- Resp no 279.273/SP, 33 Turma, rel. Min. Fátima Andrighi, j. 04.12.2003.

Veja-se, ainda, o seguinte precedente do STJ: "Direito do Consumidor e Processual Civil. Recurso Especial. Execução frustrada. Pedido de desconsideração da personalidade jurídica. Indeferimento. Fundamentação apoiada na inexistência dos requisitos previstos no art. 50 do CC/2002 (teoria menor). Omissão. Ofensa ao art. 535 do CPC reconhecida. 1. É possível, em linha de princípio, em se tratando de vínculo de índole consumerista, a utilização da chamada Teoria Menor da desconsideração da personalidade jurídica, a qual se contenta com o estado de insolvência do fornecedor, somado à má administração da empresa, ou, ainda, com o fato de a personalidade jurídica representar um 'obstáculo ao ressarcimento de prejuízos causados aos consumidores' (art. 28 e seu $\$ 5^{\circ}$ CDC). 2 . Omitindo-se o Tribunal a quo quanto à tese de incidência do art. $28, \$ 5^{\circ}$, do CDC (teoria menor), acolhe-se a alegação de ofensa ao art. 535 do CPC. 3. Recurso especial parcialmente conhecido e provido" - REsp. no 1.11.153, rel. Min. Luis Felipe Salomão, 4⿳亠丷厂 Turma, j. em o6.12.2012. 21 ALVES, Alexandre Freitas de Assumpção. A desconsideração da personalidade jurídica e o Direito do Consumidor: um estudo de direito civil constitucional, in: Problemas de Direito Civil-Constitucional. Rio de Janeiro: Renovar, 2000, p. 272. 
Não é vislumbrada nenhuma inadequação ao conteúdo no texto sob comento, ao contrário, ele expressa os valores elegidos pelo legislador constituinte em duas passagens de suma importância da Carta Constitucional. Como referido anteriormente, a proteção ao consumidor é colocada pela Constituição como Direito Fundamental (art. $5^{\circ}$, XXXII) e também erigida a princípio norteador da Ordem Econômica (art. 170, V). Nada impede a edição de norma que excepcione o sistema de limitação de responsabilidade societária. Para confirmar tal assertiva basta que se recorde que as formas societárias previstas na Codificação Civil não contemplam a limitação de responsabilidade em suas características, embora sem utilização em função de questões de ordem práticas.

O Direito do Consumidor ostenta peculiaridades que justificam a existência de regramento não coincidente com aquele destinado ao direito comum. Há um nítido interesse público na matéria consumerista de trocas e prestações de serviços que movimentam o mercado e permitem a circulação das riquezas, com inevitáveis repercussões no âmbito das relações privadas, de forma a proporcionar a efetiva tutela dos consumidores ${ }^{22}$. A necessidade de consumo, o caráter preponderantemente de adesão das relações contratuais de massa e a disparidade de forças econômicas em desfavor do consumidor impõem a existência de normas mais rígidas, capazes de amenizar a ausência de equivalência entre os contratantes.

Entende-se que a vida do dispositivo em questão deverá ser estabelecida pelo intérprete, norteado pela técnica hermenêutica tradicional de harmonizar o enunciado do caput do artigo com a previsão presente no $\S 5^{\circ}$. Assim, a cláusula geral inserta no parágrafo em questão, não poderá ser aplicada de forma a tornar inócua a previsão do caput do artigo 28 da Lei Consumerista. No mesmo sentido, não pode ser ignorado o texto do parágrafo, deixando-se de aplicá-lo, por apego literal ao mandamento contido no caput. A conciliação necessária e inquestionável deverá passar pela ideia de que o parágrafo proporcionou uma abertura do rol de casos autorizadores da aplicação da teoria da desconsideração previstos no caput do artigo, sem o prejuízo dos pressupostos teóricos que a doutrina da desconsideração da personalidade dos entes coletivos que o legislador consumerista visou consagrar na criação do artigo 28 . Como afirma Luiz Antônio Rizzatto Nunes, o $§ 5^{\circ}$, do referido dispositivo normativo, deixa patente que as hipóteses elencadas no seu caput são meramente exemplificativas, sendo o seu intuito, acima de tudo, garantir sempre o ressarcimento do consumidor pelos danos provocados pelo fornecedor ${ }^{23}$. Assim, a cláusula geral expressa no $\S 5^{\circ}$, do artigo 28 de Código Consumerista, representa um momento de compartilhamento do Direito do Consumidor com o Direito Negocial que lhe é estranho, de forma que, por meio deste ponto contado, o aplicador do direito poderá utilizar, para justificar a incidência da teoria da desconsideração da personalidade jurídica numa determinada relação de consumo, algum dos fatos que justificam a aplicação desta teoria no macro sistema negocial, como a ocorrência de confusão patrimonial ou subcapitalização ${ }^{24}$. Desta forma, o microssistema do Direito do Consumidor poderá ostentar 22 Antonio Herman V. Benjamin, Cláudia Lima Marques e Leonardo Roscoe Bessa, nesta linha, afirmam: "este valor de proteção efetiva dos consumidores é tão grande que o CDC permite mesmo a quebra do dogma da separação patrimonial entre a pessoa jurídica e seus sócios. É o art. 28 do CDC, o qual prevê a desconsideração da personalidade jurídica em prol dos interesses dos consumidores, mesmo em casos que não há abuso" - BENJAMIN, Antonio Herman V.; MARQUES, Cláudia Lima; BESSA, Leonardo Roscoe. Manual de Direito do Consumidor, 8a ed., São Paulo: Revista dos Tribunais 2017. 23 NUNES, Antônio Rizzatto. Curso de Direito do Consumidor, 8ª ed., São Paulo: Saraiva, 2013 , p. 78.

24 O TJRS, no julgamento da Ap. Civ. no 196147912, entendeu por aplicar a teoria da desconsideração da personalidade societária, com base no $\S 5^{\mathbf{0}}$ do art. 28 do CDC, considerando a falta de idoneidade financeira da empresa administradora de consórcio ( $5^{\mathbf{a}}$ Câm. Civ., Rel. Des. Silvestre Jasson Ayres Torres). No julgamento do Ag. De Inst.v. no 595131186, a 7ª Câm. Civ. o TJRS confirmou a possibilidade de desconsideração da personalidade jurídica em favor do consumidor, com fulcro no disposto no $§ 5^{\circ}$ do art. 28 do CDC, argumentando que "Os novos rumos do Direito, na proteção do consumidor, têm evitado a constrangedora realidade consistente em verdadeiro paradoxo, qual seja o de as empresas soçobrarem, enquanto os empresários enriquecem. Por isso, em boa hora, a Lei $n^{\circ}$ 8078/9o, consagrou em seu texto a doutrina de desconsideração da pessoa jurídica, de larga aplicação no direito anglo-saxão sempre que ela serve de escudo protetivo àqueles que ingressam no mercado sem qualquer risco, constituindo empresas sem idoneidade econômica. Isso para não falar nas hipóteses teratológicas, em que a pessoa jurídica acoberta atividades manifestamente ilícitas... com efeito, a agravada descumpriu integralmente o contrato, não contestou a ação de resolução contratual e repetição do pagamento, não indicou bens à penhora, descumpriu acordo celebrado para sustar a execução da sentença e, persistindo em sua atitude olímpica, 
o domínio de realidades jurídicas que lhe são próprias e peculiares, cunhado sob medida para a sua praxis, sem, contudo, deixar de aproveitar a evolução experimentada pelo sistema maior ${ }^{25}$.

Finalizando, é oportuna a indagação sobre a melhor interpretação a ser dada à expressão "poderá desconsiderar", constante do caput do artigo 28 do Código do Consumidor, ou seja, a aplicação da teoria da desconsideração, nos casos previstos por este texto normativo é indicativo de faculdade outorgada ao julgador ou trata-se de norma de incidência obrigatória.

Domingos Afonso Kriger Filho é enfático ao manifestar-se no sentido de que a expressão em comento não encerra uma simples faculdade outorgada a ser utilizada pelo magistrado, ao seu alvedrio. Entende este autor que o juiz deverá chamar à responsabilidade os sócios que estavam na direção da empresa na ocasião da ofensa ao consumidor, sob pena de quebra da escala de valores instituída por ordem legal ${ }^{26}$. Concorda-se integralmente com esta orientação, pois comprometida com os princípios que norteiam a aplicação da legislação consumerista, dita, em seu artigo $1^{\circ}$, como norma de ordem pública e de interesse social. Portanto, verificada uma das hipóteses apropriadas para o uso da teoria da desconsideração, deve esta ser realizada, como melhor forma de realização da justiça.

O tratamento diferenciado que o ordenamento jurídico oferece à normatização da teoria da desconsideração no âmbito da esfera consumerista, além de confirmar a sua autonomia, reforça a importância que a Codificação Consumerista deposita no princípio da tutela da confiança e da efetiva reparação dos danos sofridos pelos consumidores. Nesta linha, Cláudia Lima Marques leciona que "os tribunais estaduais têm usado com razoabilidade e cautela esta norma do CDC, mas retirando dela toda a sua força, frisando que o instituo é de ser utilizado toda vez que os consumidores confiam na aparência, marca ou atuação de um sócio, empresa de grupo, e também em matéria de sucessão de empresas, erros na denominação ou razão social e facilitação do seu processo" ${ }^{27}$. Efetivamente, o consumidor, ao adquirir produtos ou contratar serviços, não possui condições de verificar as condições financeiras da pessoa jurídica com

não veio a Juízo para contraminutar o agravo. Ficou saliente frente às graves assertivas da agravante, referentemente à sua situação econômico-financeira, demonstrando, assim, que, efetivamente, não oferece àqueles que com ela contratam, qualquer garantia pelo descumprimento de suas obrigações” (Rel. Des. Luiz Felipe Azevedo Gomes).

25 Ana Carolina Rodrigues e Yolanda Silvia Sendon Rodrigues realizaram interessante pesquisa junto ao Tribunal de Justiça de São Paulo, no ano de 2015, constatando que alguns juízes de primeira instância ainda exigem, para fins de desconsideração da personalidade jurídica em relações de consumo, que os requisitos do art. 50 do Código Civil sejam cumpridos. Porém, esta leitura não tem encontrado respaldo na segunda instância, em que parte das decisões desfavoráveis à desconsideração da personalidade jurídica é reformada. As autoras informam ainda que: "também foram encontradas decisões de primeira instância desfavoráveis à desconsideração da personalidade jurídica sob o fundamento de que não foram esgotados os meios para satisfação da demanda do consumidor. Entendemos que tal argumento se coaduna com os preceitos do artigo 28 do CDC. De acordo com os resultados da pesquisa realizada, notou-se que, das decisões consideradas, $85 \%$ foram favoráveis à desconsideração da personalidade jurídica. Em primeira instância o cenário é diferente, havendo um total de cerca de $50 \%$ de decisões favoráveis á desconsideração da personalidade jurídica", concluindo "este cenário demonstra a ampla aplicabilidade da desconsideração da personalidade jurídica no âmbito das relações de consumo" (RODRIGUES, Ana Carolina; RODRIGUES, Yolanda Silvia Sendon. A desconsideração da personalidade jurídica no Código de Defesa do Consumidor. Revista de Direito Público e Economia - RDPE, ano 15, nº 57, jan.-mar. de 2017, p. 35).

26 KRIGER FILHO, Domingos Afonso. Aspectos da Desconsideração da Personalidade Societária na Lei do Consumidor. Revista de Direito do Consumidor, v. 13, jan.-mar. 1995, p. 83. No mesmo tom manifesta-se Olga Maria do Val: "De fato, tendo em vista que as normas do CDC são de ordem pública e de interesse social, podem e devem ser aplicadas de ofício pelos juízes, independentemente de solicitação das partes envolvidas, ou ainda, de prévia cognição para verificar a sua aplicabilidade. Tratando-se de normas cogentes, os poderes dos juízes são ampliados de vez que estão obrigados a propiciar a efetiva tutela das relações de consumo" entretanto, na conclusão de seu estudo a autora parece contradizer-se ao referir "mesmo tratando-se de medida excepcional, isto é, uma faculdade do juiz para aquelas hipóteses em que a pessoa jurídica constitua-se em obstáculo para a efetiva reparação de danos, o fato é que esta norma representa, no mínimo, um instrumento inibidor de condutas contrárias à ordem jurídica, um instrumento valioso para tornar eficaz a proteção do consumidor" (VAL, Olga Maria do. Responsabilidade Civil - Desconsideração da Personalidade Jurídica - Prestação de Serviços Defeituosa - Fraude à Execução - Art. 28, "Caput" do CDC. Revista de Direito do Consumidor, v. 15, p. 189/19o). Eduardo Gabriel Saad também entende pela obrigatoriedade da desconsideração: "Deflui do texto do dispositivo aqui sob análise que o juiz tem a faculdade de desconsiderar a personalidade jurídica de uma sociedade. Temos para nós que essa faculdade converte-se em dever depois de feita a prova do prejuízo do consumidor devido a uma das circunstâncias elencadas nesse mesmo art. 28 do Código de Defesa do Consumidor. O silêncio da norma nos permite concluir que semelhante decisão do juiz não depende de requerimento da parte; o procedimento é admitido ex officio" (SAAD, Eduardo Gabriel. Comentários ao Código de Defesa do Consumidor: Lei 8078/9o, de 11.9.9o, $4^{\text {a }}$ ed. São Paulo: LTR, 1999, p. 312)

27 MARQUES, Claudia Lima. Contratos no Código de Defesa do Consumidor: o novo regime das relações contratuais, 8ª ed., São Paulo: RT, 2016, p. 1.413/1414. 
está negociando, assumindo a posição equivalente à de um credor involuntário, desprovido de qualquer instrumento que lhe permita salvaguardar as suas pretensões econômicas frente ao que lhe é infinitamente mais forte e, em grande parte das vezes, invisível quanto à sua estrutura interna.

O consumidor é levado a contratar pela confiança que lhe é criada pelas sedutoras técnicas de publicidade e pelo impacto proporcionado pela marca utilizada no mercado pelo fornecedor, para a divulgação de sua atividade. A realidade do mercado consumerista propicia uma verdadeira blindagem do fornecedor, tornando-o opaco àqueles que depositam neles sua confiança, contratando seus produtos ou serviços.

Para encerrar a análise da teoria da desconsideração no Código de Defesa do Consumidor, cabe trazer a colação a colação a doutrina de Cláudia Lima Marques, no sentido de que: "é o princípio da confiança, instituído pelo $\mathrm{CDC}$, garantindo não só a qualidade dos produtos colocados no mercado, mas assegurando também como dispõe o art. 6o, inciso VI, a efetiva reparação dos danos sofridos pelos consumidores, mesmo que para isto, casuisticamente, deva-se desconsiderar um dos maiores dogmas do Direito Comercial e Civil ${ }^{28}$.

\section{ASPECTOS PROCESSUAIS DA APLICAÇÃO DA TEORIA DA DESCONSIDERAÇÃO DA PERSONALIDADE JURÍDICA}

\subsection{A Processualização da disregard doctrine}

O sistema jurídico instaurado pela atual codificação processual anuncia duas maneiras de levar a juízo o debate sobre a presença dos requisitos ensejadores da aplicação da teoria da desconsideração: por meio de pedido originário ou de forma incidental.

O tema é enfrentado de maneira originária quando o pedido de aplicação da disregard of the legal entity já é apresentado no momento da propositura da demanda, proporcionando litisconsórcio passivo ${ }^{29}$ deste o começo do processo. Nesta hipótese o sócio ou administrador (ou eventualmente a pessoa jurídica, no caso da desconsideração inversa) farão parte do processo desde o seu início, sendo citados para apresentar defesa, e o julgador decidirá tanto sobre a adequação da sua responsabilização quanto sobre o mérito da lide, ou seja, o objeto da demanda.

A alegação poderá advir, também, por meio de incidente processual, colocado na nova codificação como espécie de intervenção de terceiros, na condição de técnica de ingresso forçado no processo, com aptidão para produzir eventual litisconsórcio passivo posterior, numa ampliação subjetiva da demanda ${ }^{30}$. Tal inovação oferece uma série de vantagens, na medida em permite o debate e a eventual efetivação da teoria da desconsideração da personalidade jurídica no próprio procedimento, tornando despicienda a instauração de demanda autônoma

28 MARQUES, Claudia Lima. Contratos no Código de Defesa do Consumidor: o novo regime das relações contratuais, 8ạ ed., São Paulo: RT, 2016, p. 1.469-1470.

29 Esta é a orientação adotada pelo Fórum Permanente de Processo Civil, em seu enunciado no 125, in verbis: Há litisconsórcio passivo facultativo quando requerida a desconsideração da personalidade jurídica, juntamente com outro pedido formulado na petição inicial ou incidentalmente no processo.

3o Comentando sobre a opção da nova Codificação Processual, no sentido de inserção do incidente de desconsideração da personalidade jurídica como forma de intervenção de terceiro, Luis Alberto Reichelt anota: "o fato é que, sob o pálio do incidente em questão, o sujeito cujo patrimônio se pretende seja responsabilizado mediante a desconsideração da personalidade jurídica é 'terceiro' quando do início do debate processual. Não é ele autor, pois não é o responsável pelo pleito de tutela jurisdicional, nem é réu, dado que não é em face dele que a tutela jurisdicional foi originariamente solicitada. Com o seu ingresso na relação processual, aquele que originariamente era um terceiro passa a assumir a condição de parte, formando com o réu original um litisconsórcio passivo facultativo unitário" - REICHELT, Luis Alberto. A desconsideração da personalidade jurídica no projeto de novo Código de Processo Civil e a efetividade da tutela jurisdicional do consumidor, Revista de Direito do Consumidor, vol. 98, mar-abr, 2015, RTonline. 
ou evitando que sejam negligenciados os postulados que balizam o ideal de realização do processo justo.

No presente ensaio interessa em especial a efetivação da desconsideração da personalidade jurídica requerida na forma de incidente processual, disciplinada nos artigos 133 a 137 da Codificação Processual ${ }^{31}$. A inovação é de extrema importância e representa verdadeira dobra histórica no percurso que vem sendo trilhado pela teoria da desconsideração da personalidade jurídica no âmbito do direito interno.

Conforme a própria nomenclatura vem a expressar, o incidente de desconsideração da personalidade jurídica vai ocorrer no curso do procedimento, mediante petição devidamente fundamentada, ofertada nos próprios autos e dirigida ao juiz da causa. É indispensável que o pedido seja fundado na presença dos pressupostos adequados para a responsabilização patrimonial dos sócios, administradores ou a sociedade (na hipótese de desconsideração inversa). Caberá ao requerente apontar quem se objetiva atingir com a ampliação da responsabilidade patrimonial, apresentando sua qualificação, de modo a permitir o competente ato citatório. Deverá ser exposta, ainda, a causa de pedir e os pedidos pertinentes ao escopo do incidente. Em síntese, é uma petição postulatória.

A legitimidade ativa para postular a instauração do procedimento de desconsideração da personalidade jurídica é atribuída pelo legislador processual à parte interessada (credor), ou ao Ministério Público, nos casos em que lhe couber intervir no processo. Os pressupostos para a aplicação da teoria da disregard of the legal entity estão indicados nas regras de direito material, basicamente aqueles que constam da cláusula geral do art. 50 da Codificação Civil (desvio de finalidade ou confusão patrimonial), ou de alguma legislação esparsa que discipline a matéria objeto da demanda (como, v.g. a disposição do art. 28 da legislação consumerista).

Atendendo ao princípio maior do contraditório, no procedimento do pedido incidental de desconsideração da personalidade jurídica deverá ser realizada a citação do administrador, do sócio ou da pessoa jurídica em relação ao qual se quer estender a responsabilidade patrimonial, para que estes venham ao processo e exerçam o seu direito de defesa, trazendo as suas argumentações e requerendo a produção das provas que forem do seu interesse. A referida citação é indispensável, sob pena de vir a se caracterizar a presença de grave nulidade processual. Entretanto, até o advento da nova codificação processual o tema não se mostrava tranquilo em sede de Superior Tribunal de Justiça, onde conviviam decisões que reconheciam a nulidade da decisão de desconsideração pela ausência de contraditório prévio, com aquelas que se contentavam com a mera observância do contraditório diferido.

A citação dos sócios ou da pessoa jurídica oportuniza a estes virem ao processo e defenderem os seus interesses. Será a oportunidade da apresentação das questões de fato e de direito capazes de afastar o acolhimento do pedido de extensão da responsabilidade da pessoa jurídica aos seus sócios ou administradores, como as preliminares relativas a questões processuais, como ilegitimidade, coisa julgada, dentre outros, além dos argumentos de mérito.

31 Do incidente de desconsideração da personalidade jurídica. 133. O incidente de desconsideração da personalidade jurídica será instaurado a pedido da parte ou do Ministério Público, quando lhe couber intervir no processo. $\$ 1^{\circ}-O$ pedido de desconsideração da

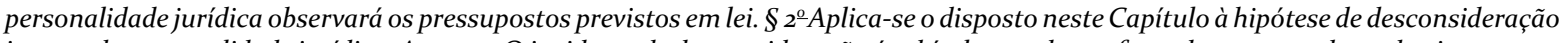
inversa da personalidade jurídica. Art. 134. O incidente de desconsideração é cabível em todas as fases do processo de conhecimento, no cumprimento de sentença e na execução fundada em título executivo extrajudicial. $\$ 1^{\circ} \mathrm{A}$ instauração do incidente será imediatamente comunicada ao distribuidor para as anotações devidas. $\$ 2^{\circ}$-Dispensa-se a instauração do incidente se a desconsideração da personalidade jurídica for requerida na petição inicial, hipótese em que será citado o sócio ou a pessoa jurídica. $\$ 3^{\circ} A$ instauração do incidente suspenderá o processo, salvo na hipótese do $\$ 2^{\circ}$. $\$ 4^{\mathrm{o} .} \mathrm{O}$ requerimento deve demonstrar o preenchimento dos pressupostos legais específicos para desconsideração da personalidade jurídica. Art. 135. Instaurado o incidente, o sócio ou a pessoa jurídica será citado para manifestar-se e requerer as provas cabíveis no prazo de 15 (quinze) dias. Art. 136. Concluída a instrução, se necessária, o incidente será resolvido por decisão interlocutória. Parágrafo único. Se a decisão for proferida pelo relator, cabe agravo interno. Art. 137. Acolhido o pedido de desconsideração, a alienação ou a oneração de bens, havida em fraude de execução, será ineficaz em relação ao requerente. 
Geralmente o deslinde do pedido de desconsideração da personalidade jurídica dependerá da realização de instrução probatória, por meio de realização de perícia técnica, ou da averiguação de situações de fato que possam indicar a ocorrência de motivos para a desconsideração. Somente assim se estará valorizando o princípio do contraditório prévio inequivocamente priorizado pelo legislador.

\subsection{Possibilidade de instauração ex officio do incidente de desconsideração nas lides consumeristas}

A novidade da normatização do incidente de desconsideração traz à tona o debate sobre a possibilidade da disregard doctrine ser efetivada ou ter o incidente instaurado de ofício pelo julgador, sem a necessidade, portanto, de provocação da parte interessada (ou do Ministério Público).

O artigo 50 da Codificação Civil é literal ao indicar que a extensão de responsabilidade em decorrência da prática de atos representativos de abuso da personalidade jurídica será efetivada "a requerimento da parte ou do Ministério Público quando lhe couber intervir no processo". Na mesma linha o artigo 133 do Código de Processo Civil reitera o Codex Civil, indicando que "o incidente de desconsideração da personalidade jurídica será instaurado a pedido da parte ou do Ministério Público”. Ainda, há a previsão contida no art. 795, $§ 4^{\circ}$, desta legislação, dispondo que "para a desconsideração da personalidade jurídica é obrigatória a observância do incidente previsto neste Código".

Logo, num primeiro momento, parece bastante sedutora a adoção de um raciocínio mais simplista, apegado à estrita dicção legislativa, levando à conclusão de que a efetivação da disregard doctrine dependeria, sempre, da postulação da parte, conforme indicado no texto da lei. Nesta trilha seguem Nelson Nery Jr e Rosa Maria de Andrade Nery, defendendo que "segundo o CPC 133, o juiz só analisará a possibilidade de desconsiderar a personalidade jurídica caso a parte interessada ou o MP requerer a providência. Não pode, pois, aplicar a desconsideração ex officio" ${ }^{2}$. André Pagani de Souza, em estudo anterior à Codificação Processual atual, já se posicionava radicalmente contrário à efetivação ex officio da disregard doctrine, considerando o seu caráter excepcional. Nas palavras deste autor: "a desconsideração da personalidade jurídica - seja ela no âmbito do direito do consumidor, seja em qualquer outra área do direito - é medida extremamente excepcional. Havendo pedido de condenação da pessoa jurídica ao pagamento de certa indenização, cabe ao juiz atender ao pedido. $\mathrm{O}$ modo pelo qual o juiz atenderá ao pleito, em se tratando de hipóteses excepcionais, deve estar vinculado ao pedido que a parte formulou", concluindo: "aliás, esse entendimento é coerente com o fato de que, caso se descubra depois que não era hipótese de se desconsiderar a personalidade jurídica, nascerá para o prejudicado um direito a pleitear indenização, e somente quem pediu e se beneficiou com essa medida excepcional é que estará legitimado a indenizar"33.

Acredita-se, no entanto, que a questão deve ser focada com base na natureza do direito material envolvido na lide, o que afasta a aceitação de uma única solução, planificada para todas as matérias, independentemente do objeto envolvido na demanda. Esta conclusão é balizada

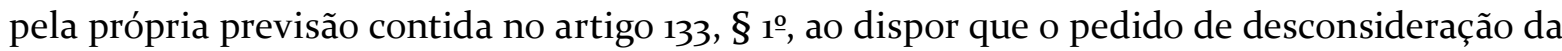
personalidade jurídica observará os pressupostos previstos em lei. Assim, se o direito material autorizar - ou justificar - a atuação de ofício do magistrado na definição da ampliação da

32 NERY JUNIOR. Nelson; NERY, Rosa Maria de. Comentários ao Código de Processo Civil, São Paulo: Revista dos Tribunais, 2015, p. 571

33 SOUZA, André Pagani. Desconsideração da personalidade jurídica: aspectos processuais, São Paulo: Saraiva, 2000 , p. 154. 
responsabilidade por decorrência da superação da personalidade jurídica, a instauração de ofício do incidente estará viabilizada ${ }^{34}$.

O Direito do Consumidor é qualificado por uma série de aspectos especiais, que permitem que seja visualizado como direito de natureza indisponível, de modo a permitir a sua aplicação de ofício pelo julgador. A Constituição Federal, em seu art. $5^{\circ}$, XXXII, eleva a defesa do consumidor à condição de Direito Fundamental; e no art. 179, V, coloca a matéria como princípio orientador da Ordem Econômica. No interior da legislação consumerista central há a indicação do Código de Defesa do Consumidor representar norma de ordem pública e interesse social (art. $1^{\mathrm{o}}$ ). Especificamente, na oportunidade em que o Código de Consumidor regula a teoria da desconsideração da personalidade jurídica (art. 28), há indicação expressa no sentido de que "o juiz poderá aplicar a teoria", o que, como enfatiza Osmar Vieira da Silva, é norma dispositiva dirigida precipuamente a juiz. De tudo, há que se concluir que a efetivação da desconsideração da personalidade jurídica nas demandas fundadas na defesa dos direitos do consumidor o juiz poderá instaurar ex officio o incidente de desconsideração, tornado despicienda a necessidade de postulação do interessado ou do representante do Ministério Público ${ }^{35}$. Seguindo-se a lição de Luis Alberto Reichelt "do ponto de vista hermenêutico, tem-se que, na dúvida entre duas ou mais interpretações resultantes do contraste entre o Código de Defesa do Consumidor e o projeto de novo Código de Processo Civil, impõe-se seja sempre adotada aquela que permita ao consumidor obter resultados mais satisfatórios ao seu interesse, sendo vedado o retrocesso" ${ }^{\text {"36. }}$.

34 Na oportunidade da I Jornada de Direito Civil, por sugestão de Kennedy Josué Greca de Mattos, foi cogitada a necessidade de ser alterada a redação do art. 50 do CC, com a proposta da seguinte redação: "Art. 50: É necessário dar nova redação ao referido artigo: Em caso de insolvência da pessoa jurídica, pode o juiz ou tribunal decretar, de ofício, a requerimento de qualquer interessado ou do Ministério Público, o fim da separação de seu patrimônio com o de seus sócios ou administradores, sempre que houver suspeita de prática de fraude, desvio de finalidade ou bens, bem como confusão patrimonial. Parágrafo único: Na hipótese prevista neste artigo, o ônus processual e econômico da prova sobre a licitude do fato, ato ou negócio jurídico praticado antes do estado de insolvência é sempre da pessoa jurídica". Tal proposta, que não chegou a lograr êxito, contou com a seguinte justificativa: "o Código Civil de 1916 sempre garantiu a total independência jurídica e econômica da pessoa jurídica e de seus integrantes. Tanto é verdade que o art. 20 da lei em vigor reza: As pessoas jurídicas têm existência distinta da dos seus membros. A norma permitiu que, ao longo dos anos, se formasse uma cultura de irresponsabilidade dos sócios frente às conseqüências nefastas da insolvência, sendo que, na maioria das vezes, terceiros de boa-fé eram prejudicados com a impossibilidade de ser reparada a lesão ao direito praticado em virtude daquela separação. Nem mesmo a jurisprudência teve forças para desconsiderar a personalidade jurídica da sociedade, já que a prova da fraude ou do abuso de finalidade sempre foi de difícil ou impossível obtenção. A redação do art. 50 da Lei no 10.406/o2 mostra-se tímida e imprecisa. Tímida, porque não adota integralmente a teoria da desconsideração da personalidade jurídica, deixando várias brechas para que as fraudes ou desvios de bens continuem sendo praticados, bastando, para tanto, que a produção da prova da prática de ato ilícito seja complexa ou onerosa. Imprecisa, quando estabelece, em sua segunda parte, que o juiz poderá estender aos bens dos sócios ou administradores os efeitos de certas e determinadas obrigações, o que certamente ocasionará um longo debate sobre quais seriam as verdadeiras hipóteses de incidência da lei. É bom lembrar, ainda, ter sido a nova lei inspirada nos princípios da eqüidade e boa-fé, conceitos que superam em muito a simples observância da gênese dos negócios jurídicos. A norma futura exige que esses princípios estejam presentes durante o desenvolvimento de toda a relação obrigacional, não apenas quando da captação da vontade dos envolvidos. Por outro lado, a transparência que o novo ordenamento quer dar às relações jurídicas, exige que haja a facilitação da investigação judicial sobre a licitude do funcionamento da empresa. Trata-se de norma de ordem pública que deve impor esse ônus àqueles que querem ter deferimento estatal para criação de nova personalidade jurídica. Além disso, também por se tratar de lei que não pode ser afastada pelas partes, deve o magistrado poder agir imediatamente, muitas vezes para evitar iminente lesão de direito. $O$ enunciado propõe, ainda, legitimar qualquer interessado a provocar a incidência da lei, porque nem sempre a vítima da lesão de direito é parte na relação obrigacional. Outro aspecto a ser salientado é que o parágrafo único agora sugerido tem a função de dar vida ao instituto da desconsideração da personalidade jurídica. Além de prever a inversão do ônus probatório, obrigação processual que passa a ser atribuída a quem detém as efetivas condições de demonstrar a verdade, já que, por exemplo, é possuidor dos livros contábeis, dos balanços, das cópias dos contratos, do levantamento do passivo e ativo etc., também impõe o adiantamento dos custos econômicos da produção da prova em juízo, tudo a fim de evitar que aqueles que sofram os reflexos da insolvência não possam utilizar o novo ordenamento jurídico devido a sua hipossuficiência".

35 Neste sentido é a orientação encontrada de Luiz Guilherme Marinoni, Sérgio Cruz Arenhart e Daniel Mitidiero, argumentado, explicando: o incidente de desconsideração da personalidade jurídica depende, em regra, de pedido da parte interessada ou do Ministério Público, quando esse participe do processo. Pode o legislador expressamente excepcionar a necessidade de requerimento para tanto - como o faz, por exemplo, o art. 28, do CDC" - MARINONI, Luiz Guilherme; ARENHART, Sérgio Cruz; MITIDIERO, Daniel. Curso de Processo Civil, v. 2, São Paulo: Revista dos Tribunais, 2015, p. 106.

36 REICHELT, Luis Alberto. A desconsideração da personalidade jurídica no projeto de novo Código de Processo Civil e a efetividade da tutela jurisdicional do consumidor, Revista de Direito do Consumidor, vol. 98, mar-abr, 2015, RTonline. Na mesa linha Osmar Vieira da Silva defende a aceitação da aplicabilidade ex officio da disregard of legal entity, argumentando: "como as situações fáticas que ensejam a desconsideração podem emergir no decorrer da instrução do processo, deve-se aceitar a possibilidade de o juiz desconsiderar a pessoa jurídica independentemente de postulação da parte autora. Tal postura não irá colidir com o princípio da iniciativa da parte, pois essa se refere à propositura da demanda. Por outro lado, estará preservando o princípio da congruência porque a tutela jurisdicional será prestada no âmbito do pedido" - SILVA, Osmar Vieira da. Desconsideração da personalidade jurídica: 
Em estudo específico sobre esta problemática, Eduardo Santos Pozza conclui pela possibilidade de instauração ex officio do incidente de desconsideração da personalidade jurídica em demanda que envolvam matéria consumerista, fundamentando o seu posicionamento, em especial, na noção de processo civil cooperativo, ressaltando, porém, a necessidade de preservação do efetivo contraditório ${ }^{37}$.

Posicionando-se neste sentido Guilherme Calmon Nogueira da Gama defende também a possibilidade de o magistrado agir de ofício também nos casos que envolvam interesse coletivo ou difuso, sem fazer qualquer distinção sobre o conteúdo de direito material envolvido e nas hipóteses relacionadas a questões de ordem pública, vinculando-se aos casos em que se reconhece a aplicação da teoria menor da desconsideração da personalidade jurídica (proteção ao meio ambiente, a tutela ao consumidor, combate à corrupção através de mecanismos ligados à pessoa jurídica $)^{38}$.

Vencido este ponto, resta verificar como será, então, a forma de atuação do julgador.

Trilhando esse caminho, Guilherme Calmon Nogueira da Gama leciona que nestes casos o magistrado, ao determinar a instauração do incidente, realizará a descrição dos fatos supostamente hábeis a ensejar a superação da personalidade jurídica, com a subsequente citação daqueles que serão atingidos pela possível ampliação da responsabilidade ${ }^{39}$.

Note-se que nada impede que o incidente de desconsideração da personalidade jurídica venha a ocorrer nas demandas que tenham por objeto relações de consumo, sendo instaurado por iniciativa do interessado ou do Ministério Público, quando então seguirá o procedimento consolidado na nova legislação processual.

\section{CONSIDERAÇÕES FINAIS}

Ao final desta breve análise sobre a teoria da desconsideração da personalidade jurídica e de sua projeção sobre os litígios envolvendo relações de consumo, é possível concluir que as peculiaridades deste setor diferenciado do Direito justificam o seu tratamento especial.

Tomando como referência o ditame constitucional, que eleva a defesa dos consumidores à condição de Direito Fundamental, qualquer inserção legislativa neste âmbito deve ser no sentido de intensificar a tutela da parte mais vulnerável destas relações econômicas de mercado, sempre direcionada à efetividade da realização de seus direitos.

Acredita-se que este foi o note do legislador consumerista ao traçar o perfil de cada figura jurídica inserida na Codificação Consumerista e que se reproduz de forma bastante satisfatória na adoção da chamada teoria menor da desconsideração, considerando suficiente a presença da insolvência para se justificar o levantamento da personalidade jurídica em favor dos consumidores.

Consolidada esta baliza, resta agora o enfrentamento da prática procedimental da aplicação da teoria da desconsideração da personalidade jurídica, frente às novas regras trazidas pela Codificação Processual Civil atual

Certamente o pensamento queiluminou os idealizadores deste Código de Procedimentos foi a prática da efetivação da teoria da desconsideração da personalidade jurídica para o direito comum, tendo como bússola a clausula geral da teoria maior, consolidada na dicção do artigo 50 do Código Civil.

aspectos processuais, Rio de Janeiro: Renovar, 2002, p. 158.

37 POZZA, Eduardo Santos. A possibilidade de instauração ex officio do incidente de desconsideração da personalidade jurídica previsto no novo Código de Processo Civil, Revista Síntese de Direito Empresarial, v. 57, jul.-ago. de 2017, p. $101-117$.

38 GAMA, Guilherme Calmon Nogueira da. Incidente de desconsideração da personalidade jurídica, Revista de Processo, v. 262 , dezembro de 2016, p. 61-81.

39 GAMA, Guilherme Calmon Nogueira da. Incidente de desconsideração da personalidade jurídica, Revista de Processo, v. 262, dezembro de 2016, p. 61-81. 
As diferenças materiais em relação à teoria maior e à teoria menor da desconsideração da personalidade jurídica não podem passar incólumes ao pensamento procedimental. Tratamse de figuras de vieses distintos, os quais necessariamente devem ser considerados na questão procedimental.

Neste sentido, defende-se a dispensa de pedido específico para a instauração do incidente de desconsideração quando a matéria versada na lide envolver questão pertinente a relações de consumo.

\section{REFERÊNCIAS}

ALVES, Alexandre Freitas de Assumpção. A desconsideração da personalidade jurídica e o Direito do Consumidor: um estudo de direito civil constitucional, in: Problemas de Direito Civil-Constitucional. Rio de Janeiro: Renovar, 2000.

AMARO, Luciano. Desconsideração da pessoa jurídica no Código de Defesa do Consumidor, Revista de Direito do Consumidor, v. 5, p. 168-182, jan-mar de 1993.

BENJAMIN, Antonio Herman V.; MARQUES, Cláudia Lima; BESSA, Leonardo Roscoe. Manual de Direito do Consumidor, 8. ed., São Paulo: Revista dos Tribunais 2017.

CÂMARA, Alexandre Freitas. Breves comentários ao novo Código de Processo Civil, Coordenadores WAMBIER, Teresa Arruda Alvim; DIDIER JR., Fredie; DANTAS, Bruno, São Paulo: Revista dos Tribunais, 2015.

COELHO, Fábio Ulhoa. Desconsideração da personalidade jurídica, São Paulo: Revista dos Tribunais, 1989.

Curso de Direito Comercial: v. 2, Direito de Empresa, 2o. ed., São Paulo: RT, 2016.

COMPARATO, Fábio Konder. Poder de controle na sociedade anônima, São Paulo: Revista dos Tribunais, 1976.

GAMA, Guilherme Calmon Nogueira da. Incidente de desconsideração da personalidade jurídica, Revista de Processo, v. 262, dezembro de 2016.

KRIGER FILHO, Domingos Afonso. Aspectos da Desconsideração da Personalidade Societária na Lei do Consumidor. Revista de Direito do Consumidor, v. 13, p. 78-86, jan.-mar. 1995.

MARINONI, Luiz Guilherme; ARENHART, Sérgio Cruz; MITIDIERO, Daniel. Curso de Processo Civil, v. 2, São Paulo: Revista dos Tribunais, 2015.

MARQUES, Claudia Lima. Contratos no Código de Defesa do Consumidor: o novo regime das relações contratuais, 8. ed., São Paulo: RT, 2016.

NERY JUNIOR. Nelson; NERY, Rosa Maria de. Comentários ao Código de Processo Civil, São Paulo: Revista dos Tribunais, 2015. 
NUNES, Antônio Rizzatto. Curso de Direito do Consumidor, 8. ed., São Paulo: Saraiva, 2013.

OLIVEIRA, José Lamartine Corrêa de. A dupla crise da pessoa jurídica, São Paulo: Saraiva, 1979.

PEREIRA, Caio Mário da Silva. Responsabilidade civil, (aspectos) no código de proteção e defesa do consumidor, desconsideração da personalidade jurídica. Revista da Academia Brasileira de Letras Jurídicas, v. 9, n. 7, p. 127-140. 2015.

POZZA, Eduardo Santos. A possibilidade de instauração ex officio do incidente de desconsideração da personalidade jurídica previsto no novo Código de Processo Civil, Revista Síntese de Direito Empresarial, v. 57, p. 101-117. jul.-ago. 2017.

REICHELT, Luis Alberto. A desconsideração da personalidade jurídica no projeto de novo Código de Processo Civil e a efetividade da tutela jurisdicional do consumidor, Revista de Direito do Consumidor, v. 98, mar-abr, 2015.

REQUIÃO, Rubens. Abuso e fraude através da personalidade jurídica (disregard doctrine). Revista dos Tribunais, v. 410, dez. 1969.

RODRIGUES, Ana Carolina; RODRIGUES, Yolanda Silvia Sendon. A desconsideração da personalidade jurídica no Código de Defesa do Consumidor. Revista de Direito Público e Economia - RDPE, ano 15, n. 57, jan.-mar. 2017.

SAAD, Eduardo Gabriel. Comentários ao Código de Defesa do Consumidor: Lei 8078/90, de 11.9.90, 4. ed. São Paulo: LTR, 1999.

SILVA, Osmar Vieira da. Desconsideração da personalidade jurídica: aspectos processuais, Rio de Janeiro: Renovar, 2002.

SOUZA, André Pagani. Desconsideração da personalidade jurídica: aspectos processuais, São Paulo: Saraiva, 2000.

TOMAZETTE, Marlon. Curso de Direito Empresarial: Teoria geral e direito societário, v. 1, 6. ed., São Paulo: Atlas, 2014.

VAL, Olga Maria do. Responsabilidade Civil - Desconsideração da Personalidade Jurídica Prestação de Serviços Defeituosa - Fraude à Execução - Art. 28, "Caput" do CDC. Revista de Direito do Consumidor, v. 15, p. 179-190, 2015.

XAVIER, José Tadeu Neves. A teoria da desconsideração da personalidade jurídica no novo Código Civil, Revista de Direito Privado, n. 10, p. 69-85, 2002. 